\title{
Escravidão, federalismo e democracia: a luta pelo controle do Estado nacional norte-americano antes da Secessão*
}

\section{Vitor Izecksohn}

Os Estados Unidos pertencem ao grupo de países para os quais a ameaça separatista constituiu um elemento central na formação de uma orientação nacionalista e na cristalização da unidade territorial. $\mathrm{O}$ período anterior à Guerra Civil é particularmente interessante no que concerne ao debate político sobre a conveniência do estado nacional. Isso se deu no contexto das lutas políticas que levariam à separação dos estados do Sul e a formação de um novo país, ainda que um país de curta duração, os Estados Confederados da América (04/1861 a 04/1865). A presença da escravidão nos estados do sul foi o elemento fundamental para a eclosão da guerra. Ela dividiu a União criada pela Declaração da Independência (1776) e pela Constituição norte-americana (1787) em duas regiōes distintas: o Norte livre e o Sul escravista. Essa divisão geográfica levou a uma crescente diferenciação nos níveis de desenvolvimento econômico, do grau de liberdade, da escala de valores e da capacidade de cada região para elaborar, desenvolver e aplicar novas tecnologias aos seus ambientes. No longo prazo esta divisão também permitiu a edificação de visões divergentes sobre o papel do governo, da divisão de poderes e do próprio exercício da democracia em cada uma das regiôes. No entanto, a relevância da escravidão como fator explicativo para a explosão da guerra tem sido prioritariamente relacionada à história econômica, ficando em menor relevo o processo de formação do estado norte-americano no período. Da perspectiva aqui esposada, o separatismo foi um elemento fundamental para o processo de constru-

\footnotetext{
* A pesquisa para este trabalho recebeu suporte financeiro do CNPq. Quaisquer discrepâncias entre as citações originais em inglês e suas traduções são de responsabilidade do autor.
}

Topoi, Rio de Janeiro, março 2003, pp. 47-81. 
ção do estado nacional nos Estados Unidos, principalmente porque a luta pelo controle do estado nacional foi um importante componente da crise que precedeu o início das hostilidades, como pretendo demonstrar no decorrer deste artigo. Estas questões serão exploradas através da análise das relações entre a escravidão e o sistema federal no contexto do debate político anterior à Guerra Civil. As discussões aqui apresentadas tomam como ponto de partida os argumentos de recentes contribuições que analisaram o debate sobre a escravidão e a guerra como componentes importantes do processo de construção do estado nacional norte-americano. ${ }^{1}$

\section{0 progresso indefinido}

Entre a independência e os anos 1850 todas as regiōes dos Estados Unidos experimentaram um grande desenvolvimento das suas capacidades econômicas, demográficas e democráticas. Até essa época nenhuma outra sociedade tinha testemunhado transformações tão rápidas num espaço de tempo tão limitado. Escrevendo no final da década de 1830 Alexis de Tocqueville observou que o que mais maravilhava um estrangeiro nos EUA era o contraste entre "a grande quantidade de obras públicas e a relativa ausência de pessoas muito ricas". ${ }^{2}$

Apesar da grande confiança proporcionada pela conjugação de progresso e mobilidade social, as transformações constantemente desafiaram o conservadorismo dos líderes da nação. Em muitas ocasiōes eles tiveram que conciliar seus ideais republicanos com as demandas provocadas pelas mudanças. A expansão territorial, o crescimento da imigração, a rápida urbanização e a industrialização apresentaram muitos desafios para a geração dos "pais fundadores". Para alguns deles, como Thomas Jefferson, da Virginia, o avanço do comércio e da indústria representou uma ameaça à manutenção da virtude cívica original. Jefferson não estava sozinho, pois muitos dos seus pares entre os pais fundadores compartilhavam dos temores de que o aumento da riqueza poderia trazer corrupção. ${ }^{3}$

De acordo com a visão jeffersoniana, a expansão comercial das repúblicas anteriores tinha sido a principal fonte de sua corrupção e decadência. A riqueza trouxera a desigualdade, intensificando o potencial para a luta de classes que ameaçava o tecido social da república norte-americana. 
Os exemplos do Império Romano, das Províncias Unidas Holandesas e, sobretudo, a experiência histórica inglesa, forneciam uma justificativa poderosa para as ressalvas de Jefferson contra o "industrialismo-comercial". Ele temia que a virtude cívica que os patriotas defenderam contra os inimigos britânicos durante a guerra de independência pudesse ser minada por forças internas. Sua linha de pensamento preconizava que a ação de uma rica minoria aristocrática poderia ser muito mais nociva à estabilidade do que a ação das multidóes urbanas. Dessa perspectiva, a concentração de riqueza seria uma fonte potencial de despotismo muito mais poderosa que o republicanismo radical defendido por alguns setores da revolução americana. Tal como sublinhado por Drew McCoy, o cerne do pensamento jeffersoniano encontrava-se na idéia de que a "sociedade americana deveria ser revolucionária...precisamente porque ela não repetiria o padrão familiar do século 18, de uma forte divisão entre os poucos proprietários e as massas de trabalhadores pobres e despossuídos" . Curiosamente, o cálculo jeffersoniano voltava-se apenas contra os industriais e comerciantes do Norte, isentando os grandes fazendeiros escravistas, que eram arbitrariamente inseridos no padrão "agricultor", sem considerar se viviam ou não do trabalho alheio. ${ }^{5}$

A eleição de Jefferson em 1800 foi o resultado da reação antifederalista contra a centralização e a legislação restritiva durante os anos 1790. Foi um movimento que recuperou as raízes do republicanismo revolucionário. De acordo com o historiador inglês John Ashworth: "Os oponentes do federalismo se aglutinaram, formaram o partido republicano-democrático e assumiram o controle do governo. Agindo dessa maneira, ao colocarem Thomas Jefferson na cabeça do governo federal, eles reestruturaram a política norte-americana e restabeleceram sua tradição democrática" . ${ }^{6}$ Dessa forma, ainda segundo Ashworth, os jeffersonianos detiveram nos Estados Unidos a onda conservadora européia que se opunha ao radicalismo da Revolução Francesa e que encontrou sua manifestação mais efetiva na formação da Santa Aliança. Em contraste com a reação européia, os Estados Unidos do início do século 19 apresentam um quadro bem diferente, com a expansão da franquia eleitoral e a inclusão dos homens brancos adultos, abrangendo até os imigrantes recém-chegados. A experiência histórica norte-americana deu assim prosseguimento à emergência da participação 
política das massas, num nível desconhecido por outras sociedades no mesmo período.?

Apesar das suas reservas a respeito da modernização estrutural e da centralização política, a administração de Jefferson foi caracterizada por políticas conciliatórias. Ele estava envolvido num movimento de mediação entre as perspectivas tradicionais e as modernizantes, buscando o equilíbrio entre os vários ramos das atividades econômicas. Dado o delicado quadro internacional com as guerras na Europa, a nação estava ansiosa demais por estabilidade para abandonar completamente a organização centralizada estabelecida pela Constituição. Portanto, o pragmatismo de Jefferson só ocasionalmente modificou o sistema hamiltoniano que prevaleceu durante a maior parte do período anterior à eclosão da Guerra Civil. ${ }^{8}$

A despeito do caráter descentralizado do sistema político nesse período, não seria correto afirmar que nenhum estado se desenvolveu nos Estados Unidos. Após a independência, a tênue organização federal existente era baseada na idéia de um estado fraco porém funcional. Na perspectiva acima esboçada o Estado nacional forneceria a estrutura essencial para o desenvolvimento comercial da nação. Isso seria feito através da criação de um mercado nacional, da coleta de direitos de alfândega, da expansão do crédito público e na proteção dos contratos. De acordo com Stephen Skowronek, os norte-americanos desenvolveram e mantiveram um estado, abarcando a organização do poder coercitivo e um senso de rotinas estáveis entre as instituições. Ele era baseado na aceitação de um conjunto de regras e de instituiçôes que, como os partidos e as cortes, tinham existência nacional. Era esse Estado de "partidos e cortes" que fazia guerras contra os índios, arbitrava as disputas entre os estados, mantinha uma ordem legal integrada numa escala constitucional, ajudava o desenvolvimento econômico e negociava tratados com outras nações. Essa estrutura limitada foi essencial para a manutenção da ordem e para o desenvolvimento social durante a primeira metade do século 19. O Estado nacional era importante sobretudo no que diz respeito a um aspecto relevante da política norteamericana no início do século, a expansão territorial. ${ }^{9}$ 


\section{Expansionismo e Escravismo}

Num contraste flagrante com os exemplos históricos clássicos que ele tanto admirava, Jefferson apoiou a expansão territorial como o meio mais eficaz de manter e expandir a virtude cívica americana. Nessa linha de ação, a disponibilidade de terras garantiria que a república continuaria a ser dominada pelo "fazendeiro independente", que simbolizava o ideal de cidadão da república. ${ }^{10}$ Os antifederalistas acreditavam que somente pelo acesso contínuo a novas terras seria possível perpetuar a possibilidade de construir uma nação de proprietários, independentes da vontade dos ricos e poderosos membros da minoria do dinheiro. Num de seus mais famosos comentários sobre o assunto Jefferson sublinhou que:

Aqueles que trabalham a terra são o povo escolhido de Deus,...

Cujos coraçôes Ele constituiu no seu depósito peculiar de virtude genuína... A corrupção da moral na massa de agricultores é um fenômeno do qual nenhuma era ou nação forneceu exemplo. Ela é a marca colocada naqueles que, não buscando o paraíso no seu próprio solo e indústria, como faz o agricultor, para sua própria subsistência, dependem para isso das casualidades e caprichos do costume. A dependência alimenta a subserviência e a venalidade, sufocando o germe da virtude e preparando as ferramentas para os desígnios da ambição. ${ }^{11}$

Nos estados do Sul este ideal pastoral oferecia um apelo mais forte do que ele podia ter nos estados do Norte. Três razões explicam esta diferença: o predomínio das atividades agrícolas; a exploração do trabalho escravo como cerne da força produtiva e a exclusão política dos negros. Nessas circunstâncias, era mais fácil para os escravistas do Sul forjar um modus vivendi compatível com as aspirações democráticas dos brancos não-proprietários de escravos, que constituíam a maioria da população. ${ }^{12}$ Jefferson, John Taylor e outros líderes do Sul sustentavam uma visão mais igualitária do interesse público. Eles defendiam a superioridade da organização social agrária sobre o ambiente urbano-industrial. Nesse mundo agrário, os fazendeiros, fossem eles escravistas ou não, podiam usufruir direitos iguais e compartilhar as mesmas aspiraçóes por liberdade e democracia. Mas essa aliança só era possível porque a ordem democrática a que eles aspiravam 
era limitada, incluindo somente os homens brancos. Essa ordem denotava o que John Ashworth denominou "igualitarismo racista". ${ }^{13}$

\section{Tabela I}

\section{Escravidão e estrutura de classes entre os brancos do sul, 1830}

\begin{tabular}{|l|l|}
\hline Não-proprietários de Escravos & $64 \%$ \\
Proprietários de 1 a 5 Escravos & $18 \%$ \\
Proprietários de 5 a 50 Escravos & $15,5 \%$ \\
Proprietários de 50 Escravos ou mais & $2,5 \%$ \\
\hline Total & $100 \%$ \\
\hline
\end{tabular}

Fonte: U.S. Bureau of the Census

No Norte, onde a escravidão não era forte e a industrialização, mais significativa, uma aliança como esta seria muito menos provável porque o conflito de classes e a ebulição social contestavam as estratégias patrícias de controle social. Nos anos iniciais da república o medo do povo e do radicalismo dominou as elites do Norte enquanto os líderes do Sul podiam ser mais consistentes nos seus apelos por participação política (mesmo quando restritos por considerações raciais). Um especialista na política sulista definiu os padrões ambíguos que determinavam o funcionamento da democracia daquela sociedade:

Os sulistas tentaram conciliar liberdade e escravidão apelando para um importante aspecto conservador da ideologia republicana. Eles proclamavam que a escravidão fortalecia o senso de igualdade entre os homens brancos e confinava o trabalho desqualificado a uma raça inferior. Todo homem branco estaria pelo menos um gigantesco degrau acima do status dos escravos e, assim, em relação aos escravos, a igualdade existiria no grupo dominante de cidadãos. ${ }^{14}$

No Sul as demandas dos brancos pobres não eram consideradas como um desafio direto ao poder escravocrata enquanto no Norte a massa de brancos pobres constituía uma ameaça potencial à manutenção da hierar- 
quia social. Desse prisma, as posições nortistas soavam inicialmente muito mais conservadoras do que as apresentadas por homens como Thomas Jefferson e, posteriormente, Andrew Jackson. Foi geralmente sob a inspiração das idéias e ações desses líderes originários do Sul que se deram os apelos pela expansão da franquia eleitoral durante a primeira metade do século dezenove. O paradoxo da democracia americana é o de uma sociedade que avança a questão do sufrágio universal masculino ao mesmo tempo em que ignora o problema da escravidão. Próximo à eclosão da Guerra Civil, o Sul era, com poucas exceçôes, tão democrático quanto o Norte e mais democrático que qualquer sistema político europeu. Tal como definido por um importante líder, a escravidão seria "o melhor governo do homem pobre". ${ }^{15}$

\section{As raízes da controvérsia seccional}

Durante a administração de Jefferson (1801-08), o território norteamericano praticamente dobrou através da compra da Louisiana à França em 1803. Os políticos jeffersonianos acreditavam que uma sociedade livre, com sua promessa de independência para o yeoman, requeria expansão territorial. $\mathrm{O}$ alargamento das fronteiras foi buscado para a aquisição de terras que pudessem perpetuar a regeneração econômica e espiritual do republicanismo democrático, mas trazia também a semente do imperialismo e do chauvinismo social, como fica claro nas palavras de Jefferson:

Por mais que os nossos interesses imediatos possam restringir nossos próprios limites, é impossível não olhar à frente para os tempos em que nossa rápida multiplicação vá expandir-nos além desses limites e cobrir todo o norte senão todo o sul do continente, com um povo que fale a mesma língua, governe de forma similar e por leis similares. ${ }^{16}$

O expansionismo entretanto não aumentou apenas o número de territórios livres que foram incorporados à nação como também franqueou uma grande porção territorial à escravidão. Uma conseqüência foi o surgimento de conflitos a respeito da expansão da escravidão para os territórios do Oeste. De acordo com Ira Berlin a expansão das culturas do algodão e do açúcar na região do vale do baixo Mississipi, que começou por volta de 
1790, transformou em poucos anos uma sociedade com alguns escravos numa sociedade escravista. Os distritos ao longo do rio Mississipi entre Natchez e Nova Orléans continham as mais altas proporções de escravos na América do Norte. Por volta de 1820 a escravidão, contrariando as previsões iniciais sobre sua extinção, era uma instituição em expansão. Um oeste escravista, paralelo ao oeste livre, estava faminto por terras. ${ }^{17}$

O sucesso da cultura do algodão e o crescimento demográfico da população escrava nativa destruíram a idéia de que a instituição iria desaparecer gradualmente. Essa perspectiva tinha ajudado a promover os compromissos feitos durante os debates constitucionais, encaixando-se como uma luva ao ideal republicano jeffersoniano, mas as transformações econômicas e demográficas modificariam esse ambiente tão propício à conciliação, conferindo à competição política um caráter progressivamente seccional. ${ }^{18}$

\section{Uma geografia assimétrica}

Originalmente, as duas maiores regiōes dos EUA mantiveram-se próximas da igualdade no que se refere ao tamanho das suas populações, das suas bancadas políticas e dos lucros com exportações. Essas circunstâncias, somadas ao elevado crescimento econômico, deram suporte ao estabelecimento de uma série de compromissos políticos eficazes, cujo acordo básico implicava a manutenção de um equilíbrio entre os estados livres e os escravistas. Estes compromissos foram fortalecidos ainda durante os debates constitucionais pela formulação de dois corpos de legislação: as Ordenanças do Noroeste e a clausula dos Três-Quintos. O primeiro acordo baniu a escravidão dos territórios situados ao noroeste do Rio Ohio. Em seguida, os representantes do Norte e do Sul enfrentaram a questão da representação dos estados no Congresso. Havia diferenças no que se referia à maneira como os escravos seriam contados para fins eleitorais. Prevaleceu o acordo segundo o qual ambos os grupos concordavam que para fins eleitorais um escravo seria igual a $3 / 5$ de um homem livre.

Um segundo ponto de consenso era o de que o governo federal não deveria interferir nas questôes internas dos estados, a não ser para proteger os interesses dos escravocratas. Inicialmente esta concepção respondeu ao receio que o crescimento do movimento federalista inspirou em muitos 
norte-americanos. A possibilidade de uma organização federal em expansão amedrontava os líderes políticos em ambas as regióes, porque ela se opunha aos impulsos centrífugos norte-americanos. Assim, o credo dos direitos dos estados dos antifederalistas insistia no direito de cada estado de governar seus próprios interesses. O problema dessa concepção estava no fato de que esse padrão de comportamento político não respondia somente à vontade popular mas a uma noção abstrata de autonomia local, isto é, cada estado como um corpo soberano, decidindo seus próprios assuntos. Se na Nova Inglaterra essa solução gerou um alto nível de autogoverno, ela também conduziu certas regiōes do Sul para uma postura conservadora no que concerne às interpretaçóes da constituição, sugerindo uma visão de mundo acentuadamente descentralizadora quanto ao papel do Estado nacional limitar a expansão de qualquer instituição não nacionalizada. Assim sendo, a doutrina dos direitos dos estados, originalmente concebida para salvaguardar as liberdades domésticas, transformou-se num argumento funcional aos interesses escravocratas: ao impedir a interferência do governo federal contra a escravidão, ela perpetuava a proeminência dos escravistas nas áreas sob seu controle. ${ }^{19}$

Até os anos 1820, a escravidão não era considerada como uma questão central no debate político norte-americano. Tampouco os ataques à escravidão eram percebidos como uma cruzada contra o Sul. Muitos líderes nortistas, que eram em princípio contrários à escravidão, assumiam que a emancipação seria gradual e não deveria causar alterações na sociedade e na economia, postergando uma ação mais efetiva contra a instituição. Muitos desses líderes acreditavam mesmo que, através de iniciativas individuais de manumissão e colonização, seria possível erradicar a escravidão nos Estados Unidos num prazo relativamente curto. A Sociedade Colonizadora Americana tinha sido fundada em 1816 assumindo como sua principal missão a tarefa de mandar ex-escravos de volta para a África, especialmente para a colônia da Libéria. Por sua vez, os sulistas viam a escravidão como um mal necessário, uma herança infeliz do período colonial. Mas os escravos eram uma forma de propriedade e o direito de possuí-los era garantido pela forma peculiar como os sulistas interpretavam a Constituição. A mesma Constituição que havia estipulado o fim do tráfico internacional de escravos para $1807 .^{20}$ 
A vitória na guerra de independência e o fim do tráfico internacional de escravos levaram muitos no Norte a acreditar que a escravidão seria abolida gradualmente. Para reforçar essa suposição existiam evidências tais como a gradual abolição nos estados do Norte, além das iniciativas individuais de manumissão em partes do Alto-Sul, tais como os estados da Virginia e Delaware. Mas a experiência norte-americana diferiu da de outras sociedades escravistas nas Américas basicamente por conta do crescimento natural da população escrava e sua progressiva concentração no Sul daquele país. Ira Berlin estima que a população escrava dos Estados Unidos passou de 697.897 em 1770 para 3.953.760 em 1860, um crescimento de aproximadamente $467 \%$ em 90 anos. A população escrava norte-americana não apenas superou como também excedeu fortemente a taxa de crescimento das populações escravas em outras partes do continente, levando o Sul a uma posição proeminente como principal usuário do trabalho escravo no novo mundo, em razão das altas taxas de crescimento natural. ${ }^{21}$

\section{Tabela II}

\section{Crescimento da população escrava nos EUA, 1790-1860}

\begin{tabular}{|ll|}
\hline 1790 & 697.897 \\
1800 & 893.041 \\
1810 & 1.191 .354 \\
1820 & 1.538 .125 \\
1830 & 2.009 .043 \\
1840 & 2.487 .455 \\
1850 & 3.204 .313 \\
1860 & 3.953 .760 \\
\hline
\end{tabular}

Fonte: Ira Berlin Slaves Without Masters, pp. 396-7

A crise do Missouri (1819-1921) forneceu o primeiro confronto mais grave entre os dois grandes blocos de interesse regional desde o final dos debates constitucionais. Em 1819 o território do Missouri solicitou admissão como estado escravista. Esse pedido e, principalmente, a maneira como os sulistas defenderam a escravidão, chocou a opinião pública do Norte, 
porque mostrou até que ponto poderia ir a defesa sulista no que se refere ao direito de estender a escravidão para o Oeste. A radicalização dos representantes do Sul mostrou que os mesmos tinham deixado de considerar a escravidão como um "mal necessário" para tratá-la como um "bem positivo". Pela primeira vez as linhas partidárias foram abaladas por interesses regionais, ameaçando a manutenção da unidade nacional.

Uma barganha conciliatória conhecida como o Compromisso do Missouri admitiu aquele estado como escravista enquanto, no futuro, a escravidão continuaria proibida nos territórios comprados à França situados acima da latitude 36’30. Para manter o equilíbrio, o território do Maine foi também admitido como um estado livre. O Compromisso do Missouri assegurou que o equilíbrio de poder entre os representantes dos estados livres e escravistas seria mantido no Senado. Mas, sobretudo, a partir de então ficou claro que a escravidão não era uma instituição arcaica, condenada a perecer sob a ação das forças do mercado. Pelo contrário, tratava-se de uma força poderosa, com potencial para expansão territorial e política, pois os representantes do escravismo no Congresso se organizariam num poderoso lobby contra a imposição de novos limites a seus interesses. Daí por diante um número cada vez maior de porta-vozes concluiriam que os direitos do Sul eram equivalentes à defesa da escravidão, cooptando a maioria branca nas suas ameaças separatistas. ${ }^{22}$

Apesar da disposição para compromissos e da forte dependência econômica que unia os interesses comerciais e industriais à plantation escravista, o desenvolvimento acelerado do Norte nas primeiras décadas do século XIX levou à diversificação econômica e ao redirecionamento do fluxo migratório, num nível que não podia ser alcançado pelos estados do Sul. Aos poucos se ampliou a diferença entre o Norte industrial e "free labor" e o Sul agrário. De acordo com James McPherson essa diferença era muito clara no que se refere à produção de tecnologia. Noventa e três por cento das 143 invenções mais importantes patenteadas nos EUA durante o período entre 1790 e 1860 vinham dos estados do Norte, com uma forte preponderância da Nova Inglaterra, que respondia por quase a metade dessa proporção. ${ }^{23}$

Durante os anos 1820 a expansão de uma economia de mercado acirrou as divergências regionais. Enquanto o Norte movia-se rapidamente na direção de um capitalismo comercial, o Sul, leal à inspiração jeffersoniana, 
manteve-se fortemente rural e agrícola. Essa assimetria não foi suficiente para colocar o Sul numa posição subalterna no contexto da nação. A política foi o canal através do qual os líderes sulistas contrabalançaram as inferioridades estruturais da sua região. Esses políticos foram capazes de colonizar muitas posições governamentais, impondo a defesa dos interesses sulistas às necessidades das bancadas do Norte. Dessa forma, o Sul escravista ao mesmo tempo controlava o Estado americano e tornava-se o mais sério adversário da sua expansão nos anos que antecederam a Guerra. O controle dessas posiçôes seria beneficiado pela ideologia política professada pelo Partido Democrata, que propunha um forte compromisso ao igualitarismo entre os brancos enquanto ignorava a existência da escravidão. ${ }^{24}$

\section{0 segundo sistema partidário}

A política norte-americana depois de 1812 foi marcada pela expansão da fronteira, pela remoção dos índios, pelo surgimento de tarifas protecionistas e pelo desenvolvimento acelerado da indústria no Norte. Uma nova forma de liderança surgiu a partir das condiçôes abertas pela expansão territorial. Ela era personificada na figura de Andrew Jackson, um herói da Guerra de 1812 e também um proprietário de escravos do estado do Tennessee. $\mathrm{O}$ apelo eleitoral de Jackson voltava-se para os valores e aspirações de um espectro amplo de grupos sociais em ambas as regióes. ${ }^{25} \mathrm{Com}$ Jackson vinha uma nova geração de líderes cujas carreiras estavam ligadas ao funcionamento de máquinas políticas. Por volta de 1820 o políticopadrão estava se tornando um especialista em oposição aos estadistas, comerciantes e latifundiários que havia dominado a carreira no período anterior. As novas organizações partidárias dependiam do trabalho de profissionais forjados nas técnicas de mobilização de massas e motivados por um grande interesse na eficiência organizacional de seus grupos. Tratava-se de homens como Martin Van Buren e seus pares da Regência de Albany, cujo status relacionava-se ao trabalho como chefes de máquinas políticas e a uma lealdade férrea às suas organizações partidárias. ${ }^{26} \mathrm{Em}$ razão da sua capacidade para a organização política, eles foram capazes de derrotar a candidatura do presidente John Quincy Adams, membro de uma das mais prestigiosas dinastias da Nova Inglaterra, que buscava a reeleição em 1828, levando Jackson para a presidência. ${ }^{27}$ 
As políticas implementadas por Jackson tornaram a presidência norte-americana menos patriarcal, dando curso ao processo de expansão do voto iniciado no início do século. De acordo com Ronald G. Walters, por volta de 1810 a maioria dos estados tinha relaxado os requerimentos exigidos para a franquia eleitoral a um ponto onde praticamente todos os homens brancos adultos podiam votar. Em 1824 somente três estados ainda restringiam de alguma forma significativa o sufrágio. ${ }^{28}$ Com Jackson no poder, a franquia não apenas foi estendida, como modificações na operação do sistema foram introduzidas. No que se refere ao processo de escolha dos candidatos majoritários destacou-se a substituição do sistema tradicional de indicação e escolha, através da reunião do caucus de notáveis ( $k$ ing caucus), pela instituição da convenção partidária, a partir do voto de delegados.

A longa mudança na direção de partidos de massa nada tinha a ver com os processos revolucionários que varreram as monarquias constitucionais européias durante os anos 1840. Tinha menos ainda a ver com a grande dependência em que se encontravam os partidos brasileiros em relação ao estado imperial constituído a partir de $1840 .{ }^{29}$ Os democratas jacksonianos viam a oportunidade social como a chave para uma ordem mais igualitária. Tais diferenças levaram à observação de Eric Foner, segundo o qual o objetivo principal dos jacksonianos “...não era a redistribuição das propriedades dos ricos, mas a abertura de vias de mobilidade social para todos os trabalhadores". ${ }^{30}$

A eleição de Jackson e o nascimento do Partido Democrata sinalizaram para grandes mudanças nas práticas políticas, que apontavam para a construção de um novo sistema partidário. Os dois partidos emergindo dessa situação iriam se mover sobre temas trazidos pela presidência de Jackson: a luta contra o Banco dos Estados Unidos, a ocupação do território mexicano, a defesa da regra da maioria, a controvérsia sobre os subsídios à indústria e a luta contra a aristocracia do dinheiro. ${ }^{31}$

O partido Democrata foi a força política hegemônica do período antebellum. Os democratas deram suporte à rápida incorporação dos imigrantes ao universo dos votantes, vindo a controlar a cidade de Nova Iorque e outros importantes portos de entrada. Sua base de apoio provinha de uma reunião heterogênea de grupos, tais como os trabalhadores urbanos, imi- 
grantes e fazendeiros de quase todas as regiōes e classes. A filosofia política do partido Democrata era fortemente influenciada pela tradição laissezfariana. Seus líderes desconfiavam da interferência governamental até mesmo no que se refere à construção de obras públicas e outras melhorias, por trás das quais enxergavam a sombra do federalismo. A filosofia política democrata foi um elemento importante para a constituição da democracia de massas nos Estados Unidos, mas também constituiu uma herança da qual o escravo estava excluído. Assim, fiel à herança jeffersoniana, essa mesma filosofia ignorava a existência da escravidão no Sul como um problema relevante da agenda política. Os escravos nunca foram considerados como fazendeiros nas plantations do Sul, enquanto as grandes questôes envolvendo a escravidão eram deliberadamente ignoradas nas sessões do Congresso pela maioria dos representantes democratas. ${ }^{32}$

Por sua parte, o partido Whig, a segunda força do sistema político jacksoniano, representava aqueles ramos dos fazendeiros do Norte e do Sul que se encontravam mais compromissados com os melhoramentos internos e um papel mais ativo do governo federal. No Norte isto implicava principalmente a defesa de tarifas protecionistas, enquanto no Sul isto passava pelo apoio à colonização do Oeste, inclusive no que se refere a uma maior presença do exército na região. ${ }^{33}$ Além das tarifas, os Whigs do Norte eram favoráveis à criação de um banco nacional como forma de dinamizar a economia. No Sul eram Whigs os fazendeiros com pretensóes mais aristocráticas ou aqueles que possuíam divergências pessoais com as lideranças democráticas de suas localidades. No seu auge, entre 1837-44, os Whigs se apresentaram como uma clara alternativa à visão negativa que os Democratas possuíam do governo federal, advogando um papel ativo para o Estado no que se refere ao desenvolvimento econômico e também às campanhas de desenvolvimento moral, incluindo a expansão da educação pública e a formulação de leis antialcoólicas. ${ }^{34}$

O partido Whig somente venceu duas das oito eleições presidenciais entre 1828 e 1852, quando entrou em crise. Nas suas duas vitórias presidenciais os candidatos eram heróis militares, não líderes políticos ou membros de maquinas eleitorais. ${ }^{35}$ No entanto, os Whigs venceram várias disputas estaduais no Norte e no Sul, além de manterem constantemente bancadas federais de bom tamanho nas duas regiōes. O maior grau de 
homogeneidade entre os Whigs não reforçou uma posição mais consistente no que se refere aos grandes debates políticos do período. Quando no poder, eles nunca foram fortes o suficiente para modificar as práticas comuns às administrações democratas, valendo-se dos mesmos recursos de seus oponentes para se manter no poder. ${ }^{36}$

O segundo sistema partidário, estabelecido nas décadas de 1820-30, tinha como características principais um agressivo clientelismo político e um padrão de competição partidária que excluía o debate dos problemas nacionais. O clientelismo retardava o processo de construção do estado na medida em que impedia a edificação de burocracias estáveis e insuladas. De acordo com David M. Potter, ambos, Democratas e Whigs “...constituíam coalizões de organizações locais antes que instituições nacionais totalmente desenvolvidas". ${ }^{37}$ Assim sendo, a disposição para o compromisso e a organização partidária contribuíram para manter o antagonismo seccional fora da agenda política, na medida permitida pelas circunstâncias. Essa disposição foi legalmente reforçada nos anos 1830-40 através da "Lei da Mordaça" ${ }^{38}$

Democratas e Whigs eram organizações nacionais com apoio em todas as regiōes, mas estavam longe de constituir organizações homogêneas. A sua composição expressava uma articulação complexa entre os interesses políticos, as afiliações étnicas e os problemas estaduais. Por mais de vinte anos esses dois partidos demonstraram as suas habilidades para conter e controlar as divergências e minimizar os conflitos entre o Norte e o Sul, impedindo que as questóes seccionais exercessem maior influência nos debates políticos. ${ }^{39}$

\section{Os partidos e o Estado}

O advento do segundo sistema partidário transformou os partidos em organizaçôes com o poder de controlar temporariamente toda a administração federal. Como intérpretes das demandas políticas locais, esses partidos encontravam-se habilitados para monopolizar muitas das tarefas que seriam normalmente exercidas por organizações burocráticas permanentes em outros países. ${ }^{40}$ Democratas e Whigs mobilizaram o eleitorado norteamericano em todos os níveis da administração pública, usando o sistema 
de espólios dos cargos públicos para motivar os seus quadros. O termo denota a capacidade dos partidos, quando no poder, para monopolizar as estruturas burocráticas, distribuindo as mesmas entre seus simpatizantes. William Marcy, um membro da Regência de Albany, descreveu essa prática em termos eminentemente bélicos, afirmando que os políticos triunfantes "proclamam como um fato estabelecido o direito às vantagens do sucesso. Eles não vêem nada de errado na regra de que os espólios do inimigo pertencem ao vencedor". ${ }^{41}$

Através da instituição do sistema de espólios a democracia americana minou a possibilidade de criação de uma burocracia independente, nos moldes da Europa continental. A maioria dos postos governamentais se tornaria prerrogativa do partido no poder. Essa configuração reforçou o papel dos partidos políticos como organizaçôes nacionais que intermediavam as relações entre o cidadão comum e o governo federal, numa escala dificilmente alcançada por qualquer instituição similar na Europa ou na América Latina. Sob essas regras constitucionais específicas os partidos políticos se tornaram as maiores fontes de geração da ordem, da continuidade, e da previsibilidade das operações governamentais. De acordo com Stephen Skowronek:

O regime de mobilização dos eleitores, de construção de coalizões partidárias e de competição nacional entre dois partidos promoveu a estrutura extraconstitucional necessária para canalizar as energias e ambiçóes dos funcionários no governo. A maquinária partidária libertou a constituição da dependência das classes patrícias, despersonalizando as relaçôes de poder, centrando suas atividades no interior da fragmentada estrutura institucional norte-americana. ${ }^{42}$

$\mathrm{Na}$ ausência de uma burocracia profissional, o sistema de "partidos e cortes" forneceu as regras operacionais para as rotinas do governo. Mesmo as posições no pequeno exército profissional estavam sujeitas à patronagem política. A identificação partidária permitiu a redução dos conflitos entre os vários níveis da estrutura constitucional, bem como alguma estabilização dos procedimentos administrativos através do clientelismo, da rotatividade nos postos e dos controles externos sobre os funcionários públicos. O sucesso na rotinização da administração pública não conseguiu, entre- 
tanto, banir completamente o problema do separatismo na política norteamericana. $\mathrm{O}$ principal desafio à unidade nacional durante o governo de Jackson veio do coração da escravidão sulista, o estado da Carolina do Sul.

\section{A crise da nulificação}

No período anterior à Guerra Civil as elites da Carolina do Sul desenvolveram uma defesa fundamentalista da escravidão, que incluiu mesmo a demanda pela reabertura do tráfico internacional. Entre 1829 e 1832, o estado, uma das poucas áreas excluídas da revolução democrática implementada à luz do sistema político jacksoniano, desafiou a administração federal ao se recusar a recolher os impostos devidos ao governo nacional. Este episódio ficou conhecido como a Crise da Nulificação. William Freehling, possivelmente o maior especialista contemporâneo neste evento, demonstrou que por trás da questão tarifária existia uma profunda insatisfação em relação à possível extensão do poder federal sobre as atribuições do estado. Este constrangimento era impulsionado pelo receio de que a elevação de tarifas sobre produtos industrializados importados viesse a se constituir no primeiro passo para uma intervenção mais efetiva do poder federal contra a existência da escravidão. Extensa pesquisa dos debates do parlamento estadual demonstrou existir maior oposição às tarifas justamente entre os representantes dos condados onde a concentração de escravos era mais expressiva. $\mathrm{O}$ problema foi resolvido com um novo compromisso, facilitado pela falta de interesse de outros estados em seguir o exemplo da Carolina do Sul. Mas o precedente estava aberto, porque o direito de qualquer estado para invocar a nulificação e neutralizar as leis federais era uma evidência da forte resistência que uma minoria regional podia apresentar às ações do governo federal. Quando essa minoria obtivesse o apoio de outros estados, como ocorreria 30 anos depois, ela poderia desencadear um processo mais amplo de separação regional. ${ }^{43}$

\section{0 crescimento das tensões seccionais}

Nos anos 1840 a integração dos territórios tomados ao México traria a escravidão para o centro do debate político. $\mathrm{O}$ expansionismo territorial 
era uma presença constante nos discursos de representantes do Sul. Várias vezes a anexação de Cuba e outros territórios coloniais espanhóis foi cogitada como solução para a ampliação de oferta de mão de obra escrava e expansão de uma fronteira agrícola servil. No decorrer da década a doutrina do Destino Manifesto converteria a maior parte do império, originalmente concebido por Jefferson para liberdade, num império para a escravidão. Pouco importava que esta política expansionista requeresse a presença de um forte Estado nacional para fazer a guerra contra naçôes mais frágeis. O Estado era bem aceito pelos sulistas desde que ele incorporasse novos territórios onde a escravidão fosse viável. ${ }^{44}$

No Norte não havia consenso sobre as políticas de expansão. A anexação do Texas como um estado escravista em 1844 e a Guerra contra o México 1846-48 foram contestadas por muitos grupos que temiam a admissão de novos estados escravistas. Eles davam razão à profecia do escritor Ralph Waldo Emerson, vaticinando que a conquista do México envenenaria os Estados Unidos, criando um império para a escravidão. ${ }^{45}$ A rápida vitória militar levou à assinatura do tratado de Guadalupe-Hidalgo que espoliou o México de quase metade do seu território. A partir de então a integração das novas terras conquistadas ao território dos Estados Unidos tornou-se o grande gargalo da política até a Guerra Civil. Em 1846 David Wilmot, deputado democrata da Pensilvânia, apresentou uma resolução banindo a escravidão dos territórios conquistados onde ela não tivesse existido previamente. ${ }^{46}$ A Emenda Wilmot (Wilmot Proviso), como essa resolução ficou conhecida, foi fonte de debates violentos no Congresso, levando a nação à beira da secessão nos três anos seguintes. ${ }^{47}$

Uma resposta conciliatória negociada pelos membros mais moderados de cada um dos partidos passou uma série de resoluções em separado até chegar a um consenso mais amplo. O Compromisso de 1850 foi a última barganha partidária bem-sucedida a manter a unidade americana por meios pacíficos. Sua principal inovação foi a substituição do Compromisso do Missouri pelas concepções de autodeterminação e soberania popular como as principais ferramentas para a determinação de quando um território poderia ser aceito como um estado livre ou escravista. Esse processo fragilizou a disciplina partidária na medida em que os deputados e senadores progressivamente se alinharam mais em função dos seus interesses regionais que das posições dos seus partidos no Congresso. 
O Compromisso também reforçou a posição do Governo Federal como um caçador de escravos a partir da introdução de uma nova Lei dos Escravos Fugitivos. Esta lei substituía o código frouxo discutido durante os debates constitucionais e sancionado em 1793. A nova lei permitia aos senhores do Sul ir ao Norte para "recuperar" seus escravos fugidos. Na execução desta tarefa teriam a proteção de Comissários Federais conduzindo investigações e autorizando o retorno dos fugitivos capturados. Os escravos capturados perderam o direito ao habeas-corpus e a qualquer forma de apelação. As cortes e sistemas legais dos estados onde esses fugitivos fossem capturados perdiam jurisdição para a interposição de quaisquer processos visando à defesa desses cativos. ${ }^{48}$

A Lei dos Escravos Fugitivos não feriu apenas a autonomia federativa dos estados do Norte, ao minar sua posição como santuários para os escravos fugitivos. Ela também criou um ambiente de medo e revolta contra o Sul, transformando a figura do "Poder da Escravidão" (Slave Power) no símbolo mais poderoso da ameaça representada pelo despotismo sulista e pela influência da escravidão sobre o governo. Segundo James McPherson, a Lei dos Escravos Fugitivos foi muito mais efetiva para a formação de uma mentalidade anti-sulista que todo o proselitismo empregado por décadas de propaganda abolicionista. Aos olhos do cidadão comum a agressividade política do Sul deu razão aos abolicionistas e outros setores do Norte que eram críticos do estilo de vida da região escravista. Estes setores vinham longamente proclamando, sem sucesso, que o trabalho escravo degradava o trabalho livre e que existiria uma conspiração sinistra dentro do governo para promover os interesses do Sul. ${ }^{49}$ Relembrando as circunstâncias da luta política nos anos 1850 o senador republicano radical Henry Wilson enfatizou as linhas principais através das quais os movimentos sulistas eram interpretados:

A completa subversão dos direitos naturais de milhões constituía um sistema antagônico às doutrinas da razão e aos movimentos da consciência, desenvolvendo um espírito intenso de orgulho e amor por distinçôes de classe, e um prazer pelo domínio. Daí surgiu o mais restritivo, dominador e agressivo dos poderes, que foi reconhecido como o poder da escravidão. ${ }^{50}$ 
A idéia de soberania popular promoveu grandes transformações no que concerne às regras de admissão dos novos estados. Ao invés das linhas geográficas herdadas das Ordenanças do Noroeste e do Compromisso do Missouri, os legisladores passaram a considerar que a forma de organização do trabalho prevalecente em cada território deveria ser sujeita a um referendo popular. Essa legislação deu aos habitantes de cada território, através das suas legislaturas e por meio de um referendum, o poder de determinar o caráter das suas instituições locais e particularmente de definir qual a forma de trabalho desejada, admitindo ou excluindo a escravidão. Confrontos sangrentos entre partidários da escravidão e free-soilers no Kansas mostraram quais seriam os resultados da aplicação do conceito de soberania popular às zonas de fronteira - massacres e atos de desobediência civil. Em 1854 um novo compromisso foi implementado pelo Congresso para dirimir os conflitos no Kansas. Mas sua eficácia era inteiramente discutível pois muitos setores do Norte viram o "Acordo do Kansas-Nebraska" como uma derrota da democracia nortista para o despotismo do Sul. As forças emergentes da oposição do Norte tirariam vantagem dessa situação, identificando-se como defensores das liberdades civis, lutando pela conquista do poder federal e prometendo banir a escravidão nos territórios do Oeste. ${ }^{51}$

A repercussão das controvérsias acima apresentadas proporcionou um rápido realinhamento partidário entre as forças descontentes do Norte. Esse processo apontava na direção de uma organização partidária claramente seccional para onde convergiam adeptos do solo livre, capitalistas, racistas e nativistas. O surgimento do Partido do Solo Livre (Free-Soiler) no final dos anos 1840 foi seguido muitos anos depois pelo nativista Partido Americano (Know Nothing). Mas essas organizaçôes careciam da força necessária para aglutinar todos os grupos descontentes numa coalizão mais sólida. Finalmente, a criação do partido Republicano, em 1854, permitiu a substituição de uma maioria Democrata nacional por uma maioria antidemocrata no Norte. Este partido expressava uma aliança entre pequenos e médios fazendeiros e grandes industriais e comerciantes. O que mantinha estes grupos unidos era sua comum aversão ao poder sulista visto como desagregador para a nação. Nas palavras do editor Horace Greely, os americanos haviam se transformado em dois povos: "um povo para a liberdade e um para a escravidão. Entre os dois, o conflito [era] inevitável". ${ }^{52}$ 
O partido Republicano, através da captura do governo federal, seria o instrumento para a redefinição do marco institucional adequado para o desenvolvimento da vida social norte-americana. Seu programa prometia empregar todo o peso do governo federal na expansão da indústria e da agricultura "livre". ${ }^{33}$ Seu apoio às tarifas protecionistas para a indústria e o aval dado à ação do Estado, no que concernia aos melhoramentos internos, uniu os interesses dos capitalistas do leste aos dos fazendeiros do Oeste. O desenvolvimento de uma ideologia que conciliava as demandas dos fazendeiros e industriais numa visão de mundo coerente ocorreu simultaneamente ao processo que identificou a plantation escravista como principal obstáculo ao desenvolvimento social. ${ }^{54}$

\section{O controle do Estado}

A década de 1850 marca a desagregação do segundo sistema partidário e a radicalização da competição política seccional, com reflexos no poder judiciário e na opinião pública de ambas as regiões.

No campo da política partidária o debate sobre a escravidão deu continuidade ao que David Davis denominou "estilo paranóico" da política do pré-guerra. Os republicanos afirmando que o Sul era dominado por uma conspiração escravista. Os democratas respondendo que os republicanos eram abolicionistas enlouquecidos por um puritanismo fanático. ${ }^{55} \mathrm{De}$ acordo com Phillip Paludan, todos os partidos acreditavam na capacidade de persuadir o povo de que sua sociedade estava arriscada a perder seus mais caros valores. Essa ansiedade dava força especial aos atritos entre o Norte e o Sul. ${ }^{56}$

No campo legal, o controle sulista sobre as organizaçōes federais foi expresso através da decisão no julgamento Dred-Scott. Esta batalha jurídica foi o resultado da apelação de um escravo à Suprema Corte. Dred-Scott tinha residido mais de dois anos em áreas livres, quando acompanhou seu senhor em missões militares. Em função dessa residência, decidiu mover um processo legal por sua liberdade quando da morte do mesmo. O processo despertou o interesse da opinião pública porque tocava no problema delicado da definição do status dos territórios em relação à escravidão. Tendo sido derrotado na corte estadual, Dred-Scott apelou para a mais alta ins- 
tância do Judiciário. Num julgamento polêmico, a Suprema Corte votou contra o pedido de Dred-Scott, mas foi além: numa decisão tida como exemplar pelos defensores da escravidão, ela estabeleceu que os habitantes negros dos Estados Unidos (livres ou escravos) não poderiam ser considerados como cidadãos e que não estavam habilitados para o gozo dos direitos constitucionais em nenhuma das unidades que compunham a Federação. Os reflexos de tal decisão não tardaram. Ela deixava claro que a passagem da escravidão para a liberdade não romperia as barreiras hierárquicas estabelecidas pela linha de cor. ${ }^{57}$ Em desespero, lideranças negras do movimento abolicionista voltaram a adotar posições pró-emigração, buscando oportunidades na África ou Haiti, ou simplesmente emigrando para o Canadá. Outros, entre os brancos, adotaram posições mais radicais. $\mathrm{O}$ líder abolicionista William Lloyd Garrison rasgou em público a Constituição norte-americana, denunciando-a como um documento favorável à escravidão. Outros setores, como o grupo comandado por John Brown, partiram para uma ação direta contra a escravidão. Em 1859 Brown, um veterano das lutas no Kansas, e um grupo de seguidores (que incluía dois dos seus filhos), atacaram o arsenal federal localizado na cidade de Harper's Ferry, no estado da Virgínia. O plano era tomar as armas e mobilizar a população escrava adjacente numa grande revolta. Com a falha deste ataque, vários dos sobreviventes, incluindo Brown, foram julgados e executados por crime de sedição. O comportamento exemplar de Brown diante de seus algozes e a dignidade demonstrada na denúncia da escravidão mobilizaram a opinião pública do Norte a tal ponto que, no dia da sua execução, os sinos das igrejas de várias cidades da Nova Inglaterra badalaram. Acabara de surgir um mártir branco na luta do Norte contra o poder da escravidão.

\section{Escravidão, espólios e Estado}

Um dos elementos centrais da perspectiva do "Slave Power" era o temor de que, usando da sua influência nos postos governamentais, os advogados da escravidão estariam tramando um plano secreto para manter a posição da instituição na política nacional. No famoso discurso "O Conflito Irreprimível”, William H. Seward, adversário de Lincoln como can- 
didato a indicação presidencial republicana, denunciou os principais elementos de tal plano, sustentando que: "Através da aplicação contínua da patronagem e da ameaça da desunião [os escravistas] vão manter uma maioria no Senado favorável a esses desígnios". ${ }^{58}$

O acirramento da defesa escravista e a radicalização política do Norte levaram à evolução do quadro político em direção ao confronto. Os republicanos rapidamente substituíram os Whigs em muitas áreas do Norte, vindo a conquistar governos estaduais e expressivas bancadas. Sua plataforma pregava a limitação da escravidão aos estados onde ela existia, restringindo sua expansão para os territórios do Oeste. Dada a estrutura do sistema de espólios, a conquista do governo federal permitiria aos republicanos varrer os representantes do escravismo dos seus postos no governo federal. ${ }^{59} \mathrm{O}$ partido encontrava-se profundamente comprometido com uma forte intervenção governamental nas áreas de infra-estrutura e no sistema judiciário. Alguns setores retratavam o partido como "o defensor do homem branco", numa clara rejeição das relaçôes de trabalho escravistas. Outros criticavam a organização social do Sul como um experimento social inferior e atrasado. ${ }^{60}$ Lincoln mesmo reconheceria, em 1860, que uma vitória republicana na eleição presidencial daquele ano limitaria fortemente a escravidão, afirmando que "O governo Federal...tem o poder de restringir a extensão da instituição”. Em abril de 1860 o Senador Henry Wilson abordou o mesmo tema de uma forma ainda mais radical, vinculando o controle do Estado à luta contra o poder da escravidão. Num discurso em Boston, ele prometeu que no poder os republicanos deveriam:

... acabar com a expansão da escravidão e resgatar o governo das garras do poder escravista. Nós devemos apagar a escravidão da capital nacional. Devemos cercar os estados escravistas com um cordão sanitário de estados livres e, em alguns anos, não obstante os imensos interesses congregados na causa da opressão, nós devemos dar liberdade aos milhôes em servidão. ${ }^{61}$

Segundo Richard Bensel, o Estado que os nacionalistas norte-americanos tentaram estabelecer durante a convenção constitucional de 1787 havia se transformado, por volta de 1860, numa estrutura “...cuja soberania era interpretada pela administração central como dependente do consentimento dos estados". ${ }^{62}$ Apesar da estrutura descentralizada do estado e 
das pequenas dimensões do governo federal, o seu poder em 1860 era suficientemente relevante para provocar os temores dos escravocratas de que sua ascendência sobre os grupos sociais subalternos estaria em perigo, caso a administração federal fosse conquistada por um grupo adverso à escravidão. A posição antiescravista dos republicanos interferia com a força de trabalho, enquanto a mensagem free-soiler ameaçava a aliança com os setores livres da sociedade sulista. A interferência federal poderia afetar a operação de algumas instituições essenciais, como o sistema judiciário e os correios, bem como a operação de práticas tradicionais de patronagem que envolviam as relações entre os estados e o governo federal. Dada a estrutura do sistema de espólios, a conquista do governo federal permitiria aos republicanos varrer os representantes do escravismo dos seus postos no governo federal. De acordo com David Potter, por volta de 1860 as elites do Sul temiam perder sobretudo "... o poder de nomear juízes, coletores de impostos e carteiros no sul”. ${ }^{63}$ A perda da capacidade de nomeação, acreditavam, poderia desestabilizar seu poder no interior das plantations. Esse estado de espírito foi expresso de maneira exemplar num editorial publicado por um jornal sulista em outubro de 1860. Indagando sobre a posição subalterna que caberia ao Sul numa administração nacional republicana ele afirmava que:

Se, na nossa posição atual de poder, tivemos o ataque de John Brown... quais não seriam as medidas de insurreição e radicalismo que devem se seguir a nossa notória e abjeta prostração à regência abolicionista em Washington, com toda a patronagem do governo federal e a organização da União no sul dando suporte? ${ }^{64}$

Thomas R. R. Cobb, um dos líderes políticos do estado da Geórgia, resumiu a precariedade da posição sulista sob as regras de um governo federal republicano:

Somente o setor executivo do governo pode nos proteger. Somente o presidente pode convocar o exército e a marinha. Somente o presidente pode designar comissários, marechais e juízes para executar a lei dos escravos fugitivos. Somente o presidente pode nos proteger de invasões armadas e dos conspiradores incendiários. Se já é tão tênue o que podemos esperar de um presidente amigo — o que podemos esperar de um adversário?65 
Pelo final da década de 1850 as chances de um conflito iminente entre o Norte e o Sul eram claras. Na medida em que os líderes do partido Democrata do Norte e do Sul começaram a divergir entre si, o partido se dividiu, deixando o espaço aberto para que a próxima eleição presidencial fosse definida pelo partido majoritário no Norte. Desse momento em diante nenhum acordo seria capaz de manter os estados do Sul na União. Para muitos sulistas a proteção federal à escravidão nos territórios era uma obrigação constitucional. Para eles qualquer violação desse princípio constitucional justificaria a separação.

A eleição do Republicano moderado Abraham Lincoln, em novembro de 1860, instigou a crise final através da qual a maioria dos estados do Sul separou-se da União. Ela parecia confirmar a materialização dos piores pesadelos escravistas, quando alguns escravos na Carolina do Sul foram chicoteados após celebrarem a eleição de Lincoln. Eles entoavam um hino religioso cujo refrão dizia: "We'll soon be free Till the Lord shall call us home". Testemunhas acusaram os escravos de modificar deliberadamente a letra do hino, cantando "the Yankee", ao invés de "the Lord". ${ }^{66}$

\section{Recapitulando...}

O pesquisador que se aventure na história dos Estados Unidos enfrenta, desde cedo, problemas de orientação. Existe grande dificuldade para a detecção de pontos de referência comuns a outras trajetórias históricas: Onde está o estado nacional? Qual o peso dos conflitos sociais na determinação das alianças políticas? Como pensar o problema da construção do estado numa sociedade cuja base de cálculo é o federalismo exacerbado? Em minha opinião grande parte da dificuldade encontra-se na reificação da própria visão norte-americana sobre os Estados Unidos, da idéia de que o papel relevante exercido pela conjugação de liberalismo, individualismo, igualitarismo e democracia, teria tornado a história norte-americana excepcional quando comparada à trajetória européia, dotando os Estados Unidos de profunda orientação antiestatista. ${ }^{67}$ A prevalência deste "credo" muitas vezes mascarou a natureza da sociedade norte-americana e suas similaridades e interconexões com outras nações. ${ }^{68}$ Assim, não seria o caso propriamente de identificar ausências, tal como pretendido pelos defen- 
sores da tese excepcionalista, mas de procurar a forma específica como o processo de construção do estado nacional é apresentado aos interessados de outros países. A forma através da qual o estado se materializou, durante o século 19, nem sempre foi evidente, mas suas funções não deixaram de ser exercidas, mesmo que o fossem por um grupo de instituições cuja homogeneidade estava longe de ser clara. ${ }^{69}$

Este artigo destacou o processo de formação do estado nacional norte-americano como um importante componente dos conflitos que desaguaram no processo de separação dos estados do Sul após a conquista do governo federal pelo partido Republicano. Este processo esteve inextricavelmente relacionado aos conflitos entre partidários do trabalho livre e do trabalho escravo. $\mathrm{O}$ acirramento dessa questão foi provocado por dois fatores principais: a expansão territorial e o realinhamento partidário da década de 1850. Enquanto o sistema político mostrou-se flexível o suficiente para acomodar os interesses regionais divergentes, foi possível manter a unidade nacional norte-americana sem guerras. Durante os anos 1820 e 1830, crises como a admissão do Missouri e a Nulificação não quebraram a unidade nacional. Mas a aquisição de metade do território mexicano na guerra de 1848 trouxe um conjunto enorme de tensões que não puderam ser acomodadas pelas ferramentas proporcionadas pelo segundo sistema partidário. $\mathrm{O}$ crescimento das divergências envolvendo a expansão da escravidão para o Oeste erodiu as bases dos compromissos iniciais, abrindo caminho para a formação de alinhamentos seccionais. Durante os anos 1850 esse sistema entrou em colapso devido à influência de uma forte competição regional. Sob a pressão desses interesses, o segundo sistema partidário foi destruído e uma organização claramente regional, o partido Republicano, emergiu para reivindicar os interesses do Norte. O conflito sobre a permanência da escravidão não era novo, mas seu acirramento, a partir de 1850, enfraqueceu os grupos que durante a primeira metade do século haviam lutado tenazmente pela manutenção da União por meios pacíficos.

A desconfiança de que um dos lados utilizaria o controle do Estado para impor sua agenda imediata no que concerne à forma predominante de organização social selou o destino dessa divergência na direção da separação e da guerra. Os líderes do Norte acreditavam que os sulistas estavam 
quebrando as regras estabelecidas nos anos 1820, ao mesmo tempo em que tentavam dominar o governo federal para expandir a escravidão. O partido Republicano proclamava que não interferiria com a escravidão nos estados em que ela ainda existia, ao mesmo tempo em que não se mostrava disposto a conceder qualquer influência aos sulistas no que se referia à formulação das políticas federais. Por sua parte, os sulistas não se mostravam dispostos a quaisquer movimentos conciliatórios, porque temiam que a perda do controle do governo pudesse privá-los do poder de preservar a escravidão. Eles acreditavam que o confinamento da escravidão aos estados mais antigos iria destruí-la rapidamente ao privá-la das terras férteis do Oeste.

No final dos anos 1850, os sulistas estavam lutando contra a regra da maioria, na medida em que buscavam a proteção do governo federal a seus direitos minoritários na política nacional. Em outras palavras, eles estavam lutando para incrementar e manter a sansão extraterritorial das suas leis estaduais. Isto significava fazer com que os códigos escravistas do Sul fossem implementados e cumpridos pelo governo federal, agindo em favor dos interesses desses estados em outras áreas da União. Tal procedimento constituía uma barreira intransponível à expansão do Estado federal, porque a defesa bem sucedida dos interesses da plantation apontava para a neutralização da autonomia estatal, no que concerne a coordenação das regras e práticas que coordenariam a expansão para o Oeste. Essas ações fundamentaram a afirmação de Frederick Douglas, o mais importante dos líderes abolicionistas negros, segundo o qual "a escravidão constituía um poder maior que o Estado". ${ }^{70}$

De forma ambígua, a secessão sulista constituiu um evento que facilitou a formação do estado norte-americano, porque a desunião permitiu a identificação do partido Republicano com o estado central, levando a um crescimento maciço da autoridade governamental no Norte nos anos seguintes. ${ }^{71}$ Com a separação do Sul, o governo central, o partido Republicano e os imperativos da economia política do norte tornaram-se profundamente inter-relacionados. Desse momento até o final da Reconstrução (1876), os interesses da expansão estatal e do partido Republicano eram praticamente análogos. No entanto, às vésperas da guerra, as dimensões do movimento separatista do Sul ainda não tinham sido devidamente com- 
preendidas. ${ }^{72}$ A maioria dos políticos e formadores de opinião do Norte concordava com a observação do deputado republicano Carl Schurz, segundo o qual "o Sul se separaria, tomaria dois drinques e voltaria para a União". ${ }^{73}$ Os eventos mostrariam que essa profecia havia subestimado a capacidade etílica dos habitantes da Confederação, bem como sua disposição para se separarem do resto do país. Para restaurar a União seriam necessários quatro anos de guerra, a destruição da escravidão no Sul e a reorganização da economia política da confederação pela coalizão vencedora.

\section{Notas}

${ }^{1}$ Nesse sentido, meu trabalho é tributário dos autores que nos últimos 20 anos relacionaram a escravidão e o separatismo como componentes interligados do processo de construção do estado nacional norte-americano, incluindo Stephen Skowronek [1982], Building a New American State. The Expansion of National Administrative Capacities, 1877-1820. Nova Iorque: Cambridge University Press, 1983; Charles C. Bright, "The State in the United States During the Nineteenth Century”. In Charles C. Bright e Susan Harding (orgs.) Statemaking and Social Movements: Essays in History and Theory. Ann Arbor: University of Michigan Press, 1984, pp. 121-158; Richard Frank Bensel, Yankee Leviathan. The Origins of Central State Authority in America, 1859-1877. Nova Iorque: Cambridge University Press, 1990; Theda Skocpol, Protecting Soldiers and Mothers. The Political Origins of Social Policy in the United States. Cambridge: Harvard University Press, 1995; David Osher, Soldier Citizens for a Disciplined Nation: Union Conscription and the Construction of the Modern American Army. Tese de Doutorado, Universidade de Columbia, 1992 e John Ashworth, Slavery, Capitalism and Politics in the Antebellum Republic. Nova Iorque: Oxford University Press, 1995.

${ }^{2}$ Alexis de Tocqueville [1835, 1840]. Democracy in America. Nova Iorque: Anchor Books, 1969, p. 554.

${ }^{3}$ Sobre a utopia jeffersoniana, ver Joyce Appleby, Origins of Jeffersonian Democracy: Republicanism, the Class Struggle, and the Virtuous Farmer. Lanham: Lexington Books, 2000, especialmente o capítulo VII “The Virtuous Farmer”, pp. 153-64.

${ }^{4}$ Drew R. McCoy, The Elusive Republic. Political Economy in Jeffersonian America. Chapel Hill: University of North Carolina Press, 1983, p. 66.

${ }^{5}$ Para Peter Kolchin, a oposição de Jefferson à escravidão fundamentou-se mais no mal que ela fazia aos brancos do que no dano que causaria aos negros. Após a independência ele se tornou crescentemente cauteloso em suas críticas à instituição, preocupado com os perigos que um assalto descuidado poderia trazer para a base da fábrica social do Sul. Peter Kolchin, American Slavery, 1619-1877. Nova Iorque: Hill and Wang, 2000, p. 88.

${ }^{6}$ Para os norte-americanos do início do século XIX o partido Federalista representava exatamente o oposto da idéia federalista, reapresentava um governo forte e centralizado. 
Alexander Hamilton, a principal liderança federalista, almejava a um aumento da centralização política, preconizando a industrialização e o reforço das capacidades militares como pré-requisitos para o estabelecimento de uma economia política republicana. A utopia hamiltoniana não era a de uma economia agrária virtuosa, mas de um estado moderno tão poderoso e avançado como a Inglaterra. Drew R. McCoy, The Elusive Republic, pp. 121-23.

${ }^{7}$ Ashworth, op. cit., p. 66.

${ }^{8}$ A intenção fundamental dos constituintes americanos de 1787 era criar a unidade política e fortalecer a autoridade do Estado. Tal como assinalado por William Riker, a maioria dos delegados presentes na convenção de Filadélfia considerava que os mecanismos criados pelos artigos da Confederação de 1776 eram demasiadamente ineficazes diante da necessidade de contar com o acordo unânime dos estados para adotar decisóes em nível nacional. A facção jeffersoniana se formou em resposta ao que consideravam como o fortalecimento excessivo da autoridade central, em detrimento dos direitos dos estados. William Riker, "The Experience of Creating Institutions: The Framing of the United States Constitution". In Jack Knight e Itai Sened (orgs.) Explaining Social Institutions. Cambridge: Cambridge University Press, 1995, p. 126.

${ }^{9}$ Skowronek, op. cit., pp. 24-25.

${ }^{10} \mathrm{Na}$ falta de melhor tradução, a partir deste ponto me referirei diretamente aos yeoman.

${ }^{11}$ Thomas Jefferson [1785], Notes on the State of Virginia. Nova Iorque: Harper \& Row, 1964, Questão XIX.

${ }^{12}$ Sobre a trajetória do ideal pastoral na cultura norte-americana, ver o livro de Leo Marx. The Machine in the Garden: Technology and the Pastoral Ideal in America. Nova Iorque: Oxford University Press, 1964.

${ }^{13}$ Ashworth, op. cit., p. 21.

${ }^{14} \mathrm{~J}$. William Harris, Plain Folk and Gentry in a Slave Society. White Liberty and Black Slavery in Augusta's Hinterlands. Middletown: Wesleyan University Press, 1987, p. 190.

${ }^{15}$ Joseph E. Brown, Governador da Georgia na época da secessão. Citado por Steven Hahn, The Roots of Southern Populism: Yeoman Farmers and the Transformation of Georgia Upcountry, 1850-1890. Nova Iorque: Oxford University Press, 1983, pp. 86-7.

${ }^{16}$ Citado em Frederik Merk, Manifest Destiny and Mission in American History. Nova Iorque: Vintage Books, 1963, p. 9.

${ }^{17}$ Ira Berlin, Slaves Without Masters. The Free Negro in the Antebellum South. Nova Iorque: Pantheon Books, 1979, pp. 225-57.

${ }^{18}$ Para a expansão da fronteira sulista e suas repercussões no tráfico interno de escravos, ver Michael Tadman Speculators and Slaves. Masters, Traders, and Slaves in the Old South. Madson: The University of Wisconsin Press, 1989. Tadman demonstra que o incremento do tráfico após 1830 ultrapassou em importância as migrações de fazendeiros (com seus plantéis inteiros). A descrição feita por Tadman apresenta semelhanças muito fortes com a situação dos escravos brasileiros após 1850. (Tadman, 1989, pp. 2-11.) Para as idéias e 
instituições ligadas ao comércio de escravos nos EUA, ver Edward E. Baptist, "Cuffy," "Fancy Maids," and "One Eyed Men": Rape, Commodification, and the Domestic Slave Trade in the United States. In The American Historical Review, Vol. 106, no. 5, 2001, pp. 1619-50.

${ }^{19}$ Curiosamente o mesmo argumento seria usado anos mais tarde, sem o mesmo sucesso, pelos membros da seita mórmon, para defender a inclusão do território de Utah como estado, mantendo-se a existência da poligamia como legítima forma de casamento civil. Bensel, Yankee Leviathan, p. 151.

${ }^{20}$ Para a ação política dos setores escravistas, durante as primeiras décadas da república, ver Paul Finkelman, Slavery and the Founders: Race and Liberty in the Age of Jefferson. Nova Iorque: Sharpe, 1999. De acordo com Finkelman, a defesa da escravidão foi uma questão central no processo de fundação dos Estados Unidos. Com essa finalidade, os escravocratas teriam dominado o governo entre 1787 e 1819. Finkelman, pp. 3-21.

${ }^{21}$ Robert William Fogel e Stanley L. Engerman, Time on the Cross. The Economics of American Negro Slavery [1974]. Nova Iorque: W. W. Norton \& Company, 1989, pp. 3-12.

${ }^{22}$ Sobre a aliança com os setores sem escravos e a manipulação das elites sulistas, ver William L.Barney, The Secessionist Impulse: Alabama and Mississippi in 1860. Princeton: Princeton University Press, 1974, pp. 15-18 e Robert R. Russel, "The Effects of Slavery upon Nonslaveholders in the Ante Bellum South”. In Agricultural History, no. 14, 1941: 54-71.

${ }^{23}$ James M. McPherson, The Battle Cry of Freedom. The Civil War Era. Nova Iorque: Oxford University Press, 1988, p. 19.

${ }^{24}$ Sobre o agrarismo sulista e os obstáculos ideológicos colocados à industrialização, ver Fred Bateman e Thomas Weiss, A Deplorable Scarcity: The Failure of Industrialization in the Slave Economy. Chappel Hill: University of North Carolina Press, 1978, pp. 132-33. ${ }^{25}$ Para um clássico sobre a vida de Jackson, ver John W. Ward, Andrew Jacksn, Symbol for an Age. Nova Iorque: Oxford University Press, 1955.

${ }^{26}$ A chamada "Regência de Albany" foi a máquina eleitoral que controlou a política do estado de Nova Iorque entre 1820 e 1854. Sua principal liderança foi Martin Van Buren, senador, governador, secretário de estado e presidente dos Estados Unidos entre 1837-41. Maiores informações sobre o funcionamento desta máquina podem ser encontradas em obras biográficas, tais como D. B. Cole, Martin Van Buren and the American Political System. Princeton: Princeton University Press, 1984 e Glyndon G. Van Deusen, Thurlow Weed. Wizard of the Lobby. Boston: Little, Brown and Company, 1947. Uma descrição ficcional do período, pode ser encontrada em Gore Vidal, Burr. Nova Iorque: Random House, 1973, recentemente traduzido para o português pela editora Rocco.

${ }^{27}$ Até a eleição de George W. Bush, em 2000, somente a família Adams teve a oportunidade de fazer pai e filho presidentes dos Estados Unidos. John Adams governou entre 1797 e 1800 e John Quincy Adams entre 1825 e 1828. Ambos foram derrotados em suas tentativas de reeleição.

${ }^{28}$ Ronald G. Walters [1978]. American Reformers, 1815-1860. Baltimore: John Hopkins University Press, 1976, p. 7. 
${ }^{29}$ Para os partidos brasileiros no período imperial, ver José Murilo de Carvalho, $A$ Construção da Ordem. A Elite Política Imperial. DF: Editora da Universidade de Brasília, 1980, pp. 155-76; Cléa Sarmento, "Estabilidade Governamental e Rotatividade das Elites no Brasil Imperial”. In Revista Dados, Vol. 29, no. 2, 1986, pp. 139-176 e Jairo Nicolau, História do Voto no Brasil. Rio de Janeiro: Zahar, 2002: pp. 10-26.

${ }^{30}$ Eric Foner, Free Soil, Free Labor, Free Men. The Ideology of the Republican Party Before the Civil War. Nova Iorque: Oxford University Press, 1969, p. 19.

${ }^{31}$ Para as especificidades do processo de modernização à Americana, ver David F. Good, "Uneven Development in the Nineteenth Century: A Comparison of the Habsburg Empire and the United States". In Journal of Economic History, no. 46, 1986, pp. 132-157.

${ }^{32}$ Os Democratas fizeram cinco dos sete presidentes do período; Andrew Jackson (182937), Martin Van Buren (1837-41), James K. Polk (1845-49) e James Buckanam (1857-61).

${ }^{33}$ Curiosamente a defesa da produção siderúrgica do Norte foi feita inicialmente à custa dos interesses sulistas. Este processo evoluiria paulatinamente, até que a proteção tarifária se transformasse num dos principais pontos de conflito entre as regiōes nos anos 1850 . Bensel, Yankee Leviathan, pp. 72-74.

${ }^{34} \mathrm{Os}$ Whigs divergiam dos democratas também quanto à questão do expansionismo. Segundo James McPherson, enquanto a noção democrata de progresso enfatizava a expansão das instituições norte-americanas pelo espaço, a noção Whig dava ênfase à expansão pelo tempo, opondo-se ao uso da força no contato com os países vizinhos. James McPherson, The Battle Cry of Freedom, pp. 48-49.

${ }^{35}$ William H. Harrison (1841) e Zachary Taylor (1849-50) foram os dois presidentes eleitos pelo partido Whig. Ambos morreram antes de terminarem seus mandatos. Uma descrição semelhante pode ser encontrada em Peter Eisenberg, Guerra Civil Americana. São Paulo: Editora Brasiliense, 1982, p. 46.

${ }^{36}$ A visão do partido Whig como uma coalizão fraca de grupos antidemocratas tem sido crescentemente questionada nos últimos 20 anos. Nesse campo se destaca o trabalho recente de Michael Holt, para quem o ponto de união entre as diversas facções Whig era a percepção de que o republicanismo encontrava-se em perigo em razão da conjunção do abuso do poder executivo (na política doméstica) com uma política externa aventureira. Michael F. Holt, The Rise and Fall of the American Whig Party: Jacksonian Politics and the Onset of the Civil War. Nova Iorque: Oxford University Press, 1999, p. 952.

${ }^{37}$ David M. Potter, The Impending Crisis, 1848-1861. Nova Iorque: Harper Torchbooks, 1976 , p. 8.

${ }^{38}$ Entre 1832 e 1846 esta lei impediu que discussões sobre a escravidão fossem travadas no plenário do congresso, chegando mesmo a banir a leitura de petiçôes e cartas que criticassem a instituição. Num desenvolvimento posterior do mesmo tema, os correios foram progressivamente impedidos de entregar correspondência de teor abolicionista em várias áreas do Sul.

${ }^{39}$ Para o processo de formação do segundo sistema partidário, ver o trabalho de Richard Hofstadter, The Idea of a Party System. The Rise of Legitimate Opposition in the United States, 
1780-1840. Berkeley: University of Califórnia Press, 1969. Michael F. Holt, The Political Crisis of the 1850's. Nova Iorque: Wiley \& Sons Inc., 1978, também fornece uma boa fonte para o estudo do funcionamento e posterior desintegração do sistema. Segundo Holt, ele teria sucumbido ao excesso de consenso, não ao conflito. Na medida em que as diferenças entre Democratas e Whigs sobre questões econômicas se estreitaram e questôes seccionais forçaram ambos os partidos a buscar compromissos. Marco Antonio Pamplona também enfocou o funcionamento do segundo sistema partidário em sua análise comparativa sobre republicanismo e cidadania. Para o estudante brasileiro o capíttulo III fornece uma boa síntese da bibliografia sobre o assunto. Pamplona, Riots, Republicanism and Citizenship. New York City and Rio de Janeiro City During the Consolidation of the Republican Order. Nova Iorque: Garland Publishing, 1996, pp. 41-66.

${ }^{40}$ Charles Bright, op. cit., pp. 123-24.

${ }^{41}$ Citado em Douglas Miller, The Birth of Modern America, 1820-1850. Nova Iorque: Macmillam, 1985, p. 159.

42 Skowronek, Building a New American State, p. 24.

${ }^{43}$ Sobre a crise da Nulificação, ver William W. Freehling, Prelude to the Civil War. The Nullification Controversy in South Carolina, 1816-1836. Nova Iorque: Oxford University Press, 1966, Eric Foner, Free Soil, Free Labor, Free Men. p. 178 e Ashworth, op. cit., pp. 136-37.

${ }^{44}$ Sobre o expansionismo norte-americano e as diferentes interpretações da doutrina do Destino Manifesto, ver McPherson, Battle Cry of Freedom, pp. 47-77.

${ }^{45}$ Ralph Waldo Emerson, citado por James McPherson, Ibid., p. 51.

${ }^{46}$ Essa decisão não passava de um eufemismo, já que a escravidão tinha sido abolida no México desde 1829. Wilmot fazia parte de um grupo dissidente de democratas que estavam cansados da dominação do partido por elementos do Sul. David M.Potter, The Impending Crisis, pp. 20-22.

47 Para David Potter, a Emenda Wilmot foi o clímax de uma série de rivalidades intrapartidárias que tomaram uma forma seccional no interior da organização democrata. Essas rivalidades incluíram as discussões sobre a redução das tarifas, o êxito de facções e o controle dos postos-chave por sulistas (ibid., p. 27).

${ }^{48}$ Uma boa descrição dos conflitos criados pela Lei dos Escravos Fugitivos pode ser encontrada em Donald G.Nieman, Promises to Keep. African-Americans and the Constitutional Order, 1776 to the Present. Nova Iorque: Oxford University Press, 1991, pp. 30-49.

${ }^{49}$ McPherson, Battle Cry of Freedom, pp. 78-91. O tratamento mais completo sobre a formação de uma opinião crítica do Sul, foi produzido por Foner, Free Soil..., pp. 40-102). Entre os panfletos da década de 1850, o de maior repercussão foi escrito por Frederick Law Olsmted. Olmsted, que ficaria mais famoso como o arquiteto do Central Park, sistematizou as impressões de três viagens ao Sul no livro "The Slave States". Estou trabalhando com a edição de 1959. No campo ficcional destacou-se o romance de Harriet Beecher Stowe "A Cabana do Pai Thomas", escrito em resposta à nova lei dos escravos fugitivos. Tradução brasileira pela editora Tecnoprint. 
${ }^{50}$ Senador Republicano Henry Wilson, citado por Michael Perman, The Coming of the Civil War. Massachusettts: D. C. Heat and Company, 1993, p. 8. Para um tratamento abrangente da questão, ver Leon L. Richards, The Slave Power, The Free North and Southern Domination, 1780-1860. Baton Rouge: Louisiana University Press, 2000.

${ }^{51}$ Ashworth, John, Slavery, Capitalism and Politics...., pp. 144, 344, McPherson, Battle Cry of Freedom, pp.148-150 e Phillip Paludan, A People's Contest: The Union and the Civil War 1861-1865. Lawrence: University Press of Kansas, 1989, p. 208.

${ }^{52}$ Citado em Foner, Free Soil..., p. 310.

53 Para o processo de formação do partido Republicano, ver William E. Gienapp, The Origins of the Republican Party. Nova Iorque: Oxford University Press, 1978.

${ }^{54}$ As posições progressistas e desenvolvimentistas dos republicanos foram discutidas em diversos trabalhos. Entre aqueles que correlacionaram essas posições com a origem social dos políticos republicanos, destacam-se William Best Hesseltine [1948], Lincoln and the War Governors. Gloucester: Peter Smith Editor, 1972; Leonard P. Curry, Blueprint for Modern America. Non-Military Legisation of the First Civil War Congress. Nashville: Vanderbilt University Press, 1968 e Alan G. Bogue, The.Earnest Men: Republicans of the Civil War Senate. Ithaca: Cornel University Press, 1981.

${ }^{55}$ David Davis, The Slave Power Conspiracy and the Paranoid Style. Baton Rouge: Louisiana University Press, 1969, pp. 265-266.

56 Phillip Paludan, A People's Contest, pp. 396-397.

${ }^{57}$ Um resumo da decisão do Chefe de Justiça Roger Taney, pode ser encontrado em Kermith L. Hall (org.), Major Problems in American Constitutional History. Volume I: The Colonial Era Through the Reconstruction. Lexington: D. C. Heat, 1989, pp. 463-470).

${ }^{58}$ Citado em George Baker, The Works of William H. Seward. Nova Iorque: MAS Press, 1972 , p. 575.

${ }^{59}$ Muitos desses republicanos como William Seward, Salomon P. Chase e o próprio Lincoln eram antigos "Conscience Whigs", desiludidos com a posição conciliatória dos Whigs do Sul.

${ }^{60}$ A posição dos republicanos com respeito aos negros ainda é objeto de controvérsia. Podese dizer que as posiçôes extremas desse debate encontram-se em Foner, Free e Soil e Reconstruction: America's Unfinished Revolution, 1863-1877. Nova Iorque: Harper and Row, 1984, para quem o partido expressava um comprometimento moral com a causa da integração e em Leon Litwack, Been in the Storm So Long. The Aftermath of Slavery. Nova Iorque: Vintage Books, 1979, para quem a simpatia não passava de oportunismo, que disfarçava o racismo endêmico dos brancos do Norte.

${ }^{61}$ Congressional Globe, 36a. Legislatura, Volume I, pp. 2590-603.

${ }^{62}$ Bensel, op. cit., p. ix.

${ }^{63}$ David Potter, The Impending Crisis, p. 477.

${ }^{64}$ Charleston Mercury, 11 de outubro de 1960. Citado em Stampp, The Causes of the Civil War. Nova Iorque: Touchstone, 1991, p. 151. 
${ }^{65}$ Discurso separatista de R. R. Cobb, proferido em 12 de novembro de 1860. Citado em William W Freehling e Craig M. Simpson (orgs.) Secession Debated. Georgia's Showdown in 1860. Nova Iorque: Oxford University Press, 1992, p. 25.

${ }^{66}$ Este incidente foi descrito nas memórias de uma ex-escrava, Susie King Taylor, que fugiu ao encontro das tropas do Norte. Ver Patrícia Romero e Willie Lee Rose (orgs.), Reminiscences of My Life. A Black Woman's Civil War Memories. Susie King Taylor. Nova Iorque: Markus Wiener Publishing, 1988, p. 32.

${ }^{67}$ Numa abordagem mais recente do tema, Seymour Martin Lipset definiu a identidade nacional norte-americana como "um compromisso ideológico", em contraste com os atributos de nascimento, que segundo aquele autor, prevaleceriam em quase todas as outras sociedades. Lipset, American Exceptionalism: A Double-Edged Sword. Nova Iorque: Norton, W. W. Company, Inc., 1997, pp. 26, 31.

${ }^{68} \mathrm{O}$ debate sobre a excepcionalidade do caso norte-americano surgiu provavelmente com a publicação do livro de Tocqueville, durante a década de 1830. O argumento foi revigorado no final do século XIX, com a publicação do discurso de Frederick Jackson Turner, "The Significance of the Frontier in American History" (1893), proferido durante sua posse como presidente da American Historical Association. Nos anos 1940-50 a prevalência de abordagens ligadas à corrente conhecida como "História Consensual" muitas vezes foi funcional à visão excepcionalista. Críticas a essa perspectiva, principalmente no que concerne aos debates sobre a classe trabalhadora, podem ser encontradas em Eric Foner, "Why is There no Socialism in the United States" In History Workshop Journal, no 17 , 1984, pp. 57-80, e Sean Wilentz, "Against Exceptionalism: Class, Consciousness and the American Labor Movement, 1790-1920" In International Labor and Working Class History, no. 26, 1984, pp. 1-24. O debate foi retomado nos anos 1990, a partir do polêmico trabalho de Lipset (1997). Este último foi objeto de críticas bastante fortes, destacando-se o fórum aberto pela American Historical Review, Volume 102, n. 3. Ver especialmente o artigo de Mary Nolan, "Against Exceptionalisms", pp. 769-744. Para um bom exemplo da tese da excepcionalidade aplicada à perspectiva comparada, ver a coletânea organizada por C. Vann Woodward (org.), The Comparative Approach to American History. Nova Iork: Basic Books, Inc., 1968. Para uma introdução ao assunto, ver Lucia Lippi Oliveira, Americanos. Representaçôes da Identidade Nacional no Brasil e nos EUA. Belo Horizonte, Editora da UFMG, 2000, especialmente pp. 19-45.

${ }^{69}$ Segundo J. P. Nettl a sensação de ausência do Estado foi comum a muitos observadores da sociedade norte-americana durante o século 19 . O vazio em relação à percepção do Estado, prosseguiu durante o século 20. Nettl, “The State as a Conceptual Variable”. In World Politics, no. 20, 1968, pp. 559-92.

${ }^{70}$ Frederick Douglas, "A Battle of Principles and Ideas", citado em Perman, The Coming of the Civil War, p. 17.

${ }^{71}$ Para este ponto, ver o trabalho de Bensel, Yankee Leviathan, pp. 303-365.

${ }^{72}$ Entre outras razões, porque vários estados do Sul contavam com expressivos segmentos das forças unionistas, isto é, que pregavam a manutenção da União como uma opção 
preferível à secessão. Muitos desses unionistas eram antigos Whigs, como era o caso do futuro vice-presidente da Confederação, Alexander Stephens. Para a relevância do unionismo em vários estados do Sul, ver Freehling, The South vs. The South. How AntiConfederate Southerners Shaped the Course of the Civil War. Nova Iorque: Oxford University Press, 2001.

${ }^{73}$ Citado em Potter, The Comming of the Civil War, p. 433.

\section{Resumo}

Este artigo analisa o processo de construçäo do Estado nacional norte-americano no período anterior à eclosão da Guerra Civil. Da perspectiva aqui esposada, o separatismo foi um elemento fundamental para o processo de construção do estado nacional nos Estados Unidos, principalmente porque a luta pelo controle do estado nacional foi um importante componente da crise que precedeu o início das hostilidades. Estas questôes são exploradas através da análise das relaçōes entre a escravidão e o sistema federal, no contexto da crise do Segundo Sistema Partidário. As discussöes aqui apresentadas tomam como ponto de partida os argumentos de contribuiçöes recentes, que analisaram o debate sobre a escravidão e a guerra como componentes importantes do processo de construção do estado nacional norte-americano.

\section{Abstract}

This article analyzes the struggle for the control of the American national state during the antebellum period. From this perspective, the secession threat was an important issue for the American state-building process, because the struggle for the control of the national state was a pivotal element of the crises that led to secession and the Civil War. These questions are tackled through the exam of the relations between slavery and the federal system in the context of the crisis of the Second Party System. The departure point of the discussion is the recent debates that assert that slavery and the War were important elements of the American state-building process. 